\title{
Assessment of the competition level in the sector of bicycle manufacturers in the Slovak Republic
}

\author{
Vladimir Hojdik ${ }^{*}$, Monika Raková ${ }^{1}$ \\ ${ }^{1}$ University of Economics in Bratislava, Faculty of Business Management, Department of Business \\ Economy, 85235 Bratislava, Slovakia (EU)
}

\begin{abstract}
Bicycle industry has recorded significant boom recently, mainly as a consequence of global pandemic situation, but also as a result of green policies of countries. The popularity of cycling is on its all-time high, which also transferred to rising sales of bicycles worldwide. This paper evaluates current situation of bicycle industry in Slovak republic, mainly with the objection on performance of Slovak bicycle producers. With use of appropriate indicators, the paper aims to assess the rate of competitiveness among Slovak bicycle producers. For this purpose, relevant indicators as market share, concentration ratio $C R_{3}, C R_{5}$, and Herfindahl index are calculated and evaluated. The aim of this paper is to analyze financial results of Slovak bicycle industry producers, then measure the degree of concentration of whole industry in order to explain industry competitiveness in context of Slovak economy.
\end{abstract}

\section{Introduction}

The bicycle industry (known as cycling industry) is the sector of economy, which is concerned by bicycles and cycling. Within the industry, many different subjects execute their activities. The industry includes especially following groups of business entities [4] :

- bicycle manufacturers,

$\circ$ component/part manufacturers,

- accesory manufacturers.

However, not only these subjects are interested in the operation of bicycle industry. Very important for the overall industry functioning are also other business groups [4] :

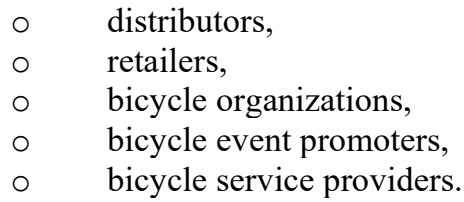

Businesses operating in this sector are cooperating together and create complex supply chains. Such cooperation is very important and any disturbance in the supply chain will

* Corresponding author : Ing. Vladimír Hojdik, PhD. : vladimir.hojdik@euba. ORCID : 0000-0001-6955-1677. 
result in the lack of final products (bicycles) on the market - the phenomenon that is present during the times of COVID-19 pandemic.

Sector of bicycle industry has recorded growing tendency in Slovak economy. Bicycle manufacturing complies to industry manufacture and it is also subcategory of manufacture of other transport equipment. It is registered by SK NACE as autonomic business activity under the statistical code SK NACE 30.92.0, which represents not only bicycle manufacture, but also wheelchair manufacture. According to data of Statistical Office of Slovakia, following key indicators are related to subjects classified as SK NACE 30.92 .0 businesses [21].

Table 1. Basic information about SK NACE 30.92.0 industry (Manufacture of other transport equipment) for years 2017-2019

\begin{tabular}{|l|c|c|c|}
\hline & $\mathbf{2 0 1 9}$ & $\mathbf{2 0 1 8}$ & $\mathbf{2 0 1 7}$ \\
\hline $\begin{array}{l}\text { Number of } \\
\text { businesses }\end{array}$ & 19 & 19 & 17 \\
\hline $\begin{array}{l}\text { Total revenues } \\
\text { (mil. EUR) }\end{array}$ & 514,7 & 406,6 & 312,3 \\
\hline $\begin{array}{l}\text { Number of } \\
\text { employees }\end{array}$ & 3872 & 3651 & 3385 \\
\hline
\end{tabular}

By the end of 2020, seven businesses in Slovak Republic were engaged in bicycle manufacturing. These businesses differ significantly in many aspects. This research analyses differences especially from revenues perspective, and then it discusses how it influences market structure and industry competition level. All in all, this paper aims to enrich the knowledge base of this research area with new findings from Slovak bicycle manufacturing industry.

\section{Methods}

The aim of the paper is to assess the dynamics of Slovak bicycle industry, with special focus on bicycle manufacturers. Particularly, it measures industry concentration, based on relevant indicators. During the research process, we used the combination of general and specific research methods. General methods (especially analysis, comparison or synthesis) were predominantly used for purposes of theoretical explanation of the topic in the introductory part of the paper. Introductory part had mainly descriptive character as it outlines current situation among Slovak bicycle manufacturing sector. However, the use of specific methods was the main part of the research to achieve the aim of the paper.

Among the specific research methods, following were used:

- mathematical and statistic methods,

- data processing with use of MS Excel interface,

○ calculation and implementation of key indicators relevant for the research: concentration ratio and Herfindahl index.

Mathematical and statistical methods enabled the quantification of indicators that measure the competitiveness level of business sector - in this case bicycle manufacturers sector. First, market share of businesses (expressed in \%) was calculated, based on total revenues of reviewed subjects. From market share values we later proceeded to quantification of another important indicator - concentration ratio.

Concentration ratio depends on market shares of businesses within the industry, and most often is identified for three $\left(C R_{3}\right)$, five $\left(C R_{5}\right)$ and ten $\left(C R_{10}\right)$ businesses with highest market share (also expressed in \%). In our research, we used $C R_{3}$ and $C R_{5}$ values. 
The final indicator was Herfindahl index (also known as Herfindahl-Hirschmann index) which measures absolute concentration of industry. Concentration ratio and Herfindahl index are two most frequently used indicators which evaluate the level of industry competitiveness [3]. Results obtained from $\mathrm{CR}_{3}, \mathrm{CR}_{5}$ and Herfindahl index quantification became the basis for evaluation of competitiveness among bicycle manufacturers in Slovak republic. In the following table, there are basic information about the research sample Slovak bicycle manufacturers.

Table 2. Basic information about Slovak bicycle manufacturers

\begin{tabular}{|l|c|c|c|}
\hline \multicolumn{1}{|c|}{ Business name } & Brand of bikes & $\begin{array}{c}\text { Number of } \\
\text { employees }\end{array}$ & Base \\
\hline Kenzel, s.r.o. & Kenzel & $20-24$ & Hurbanovo \\
\hline ISTRO - HGA, spol s r.o. & Vedora & $5-9$ & Hurbanovo \\
\hline DEMA Senica, a.s. & Dema & $25-49$ & Senica \\
\hline Belve, s.r.o. & CTM & $50-99$ & Stará Turá \\
\hline LIBERTY TRADE, s.r.o. & Mayo, Liberty & 2 & Trenčín \\
\hline KELLYS BICYCLES, s.r.o. & Kellys & $150-199$ & Vel'ké Orvište \\
\hline Cyclision s.r.o. & Cyclision & 1 & Piešt'any \\
\hline
\end{tabular}

\section{Results and discussion}

\subsection{Current situation among Slovak bicycle manufacturers}

Considering the Slovak bicycle market as a whole, there is wide variety of bicycle brands available for potential customers. These bicycle brands are made especially by manufacturers from Germany, USA, Italy, Czech Republic or China. However, only seven manufacturing companies which are currently operating on the Slovak bicycle market are from Slovakia.

With the use of website finstat.sk, we summarized financial data needed to execute the research. For the purposes of the paper, business revenues represented the most important financial metric. In the Table 2, we present total revenues of bicycle manufacturers during the five-year period between 2016-2020. Among the manufacturers with the highest revenue we can include Belve, Kellys Bicycles and Dema Senica [8]. For fiscal year 2020. data were not yet available for all companies, so in the research we later worked with estimated values.

The data in the Table 3 show the development of revenues among the observed businesses. Total revenues of Belve for 2020 have not been reported for all year (12 months), but only for nine months (*). Three manufacturers: Istro - Hga, Kenzel and Liberty Trade have not reported financial data for 2020 yet.

Table 3. Revenues of Slovak bicycle manufacturers in years 2016-2020 (EUR thousand) 


\begin{tabular}{|l|c|c|c|c|c|}
\hline \multicolumn{1}{|c|}{ Business name } & $\mathbf{2 0 2 0}$ & $\mathbf{2 0 1 9}$ & $\mathbf{2 0 1 8}$ & $\mathbf{2 0 1 7}$ & $\mathbf{2 0 1 6}$ \\
\hline BELVE, s.r.o. & $17433^{*}$ & 11155 & 10799 & 9890 & 9993 \\
\hline Cyclision s.r.o. & 568 & 245 & 171 & - & - \\
\hline DEMA Senica, a.s. & 11880 & 15537 & 10492 & 9647 & 11192 \\
\hline $\begin{array}{l}\text { ISTRO - HGA, spol } \\
\text { s r.o. }\end{array}$ & $230^{* *}$ & 230 & 284 & 316 & 372 \\
\hline $\begin{array}{l}\text { KELLYS BICYCLES } \\
\text { s.r.o. }\end{array}$ & 44655 & 32094 & 34657 & 30305 & 2674 \\
\hline $\begin{array}{l}\text { Kenzel, s.r.o. } \\
\text { LIBERTY TRADE, } \\
\text { s.r.o. }\end{array}$ & $912 * *$ & 712 & 504 & 532 & 459 \\
\hline
\end{tabular}

* estimated value, revenues reported only for 9 months

** revenues for 2020 still not reported, so we used values from previous year

The revenues progression of bicycle manufacturers remains steady during analyzed period, without any radical change in the dynamics. Kellys Bicycles holds leading position in the whole industry asi it controls approximately half of the market. For the dataset in the Table 3 we also present descriptive statistics in the Table 4 for all of observed years.

Table 4. Descriptive statistics for total revenues in years 2016-2020

\begin{tabular}{|l|c|c|c|c|c|}
\hline $\begin{array}{c}\text { Variable: revenues } \\
\text { (EUR thousand) }\end{array}$ & $\mathbf{2 0 2 0}$ & $\mathbf{2 0 1 9}$ & $\mathbf{2 0 1 8}$ & $\mathbf{2 0 1 7}$ & $\mathbf{2 0 1 6}$ \\
\hline $\mathrm{N}$ & 7 & 7 & 7 & 6 & 6 \\
\hline Mean & 10917 & 8702 & 8271 & 8605 & 4615 \\
\hline Standard deviation & 16364 & 12023 & 12585 & 11544 & 5480 \\
\hline Minimum & 230 & 230 & 171 & 316 & 372 \\
\hline Maximum & 44655 & 32094 & 34657 & 30305 & 11192 \\
\hline
\end{tabular}

\subsection{Key indicators for the research (chapter processed according to [14])}

Market competitiveness and its changes indicates what is the quality of competition in the economy. Measurement and assessment of market concentration indicators give institutions an opportunity to monitor the competitiveness of businesses which operate in specific sector of economy [16].

The literature is home to numerous methods that evaluate the degree of competitiveness within the industry. To follow the aim of this paper, indicators of absolute concentration were calculated (these indicators quantify the degree of concentration in all subjects). Among absolute concentration indicators we include concentration ratio and Herfindahl index [10]. Both indicators are based on the calculation of market share. Therefore, the fundamental data for quantification of selected indicators are total revenues of individual businesses. 
Market share is the basic indicator of concentration ratio. It represents the share of the individual enterprise revenues on the revenues of whole sector. Market share allows to determine, how the manufacturer performs in comparison to the other market participants other competing businesses. Analytically, it is possible to quantify market share by the following formula [10]:

$$
r_{k}=\frac{q_{k}}{q}=\frac{q_{k}}{\sum_{i=1}^{n} q_{j}}
$$

where $n$ - number of companies operating in the sector,

$q_{k}$ - revenues of $k$ company, $k=1, \ldots, n$,

$q$ - total revenues for whole sector,

$r_{k}$ - market share of $k$ company.

Market share can be expressed as relative or as percentage result. It takes values from the interval $<0 ; 1>$ for the first, and $<0 ; 100\rangle$ for the latter. Extreme values indicate either full concentration of the industry - monopoly for $r_{k}=1$, or the absence of market operators in the sector for $r_{k}=0$ [10].

\subsubsection{Concentration ratio (CR)}

Concentration ratio is an indicator of the market share sum held by few of the strongest industry businesses. Formula of the concentration ratio quantification is as follows [10]:

$$
C R_{\Psi}=\frac{1}{q} * \sum_{k=1}^{\Psi} q_{k}
$$

in which $\psi$ lays in the interval $<1 ; n>$ and $C R \psi$ takes values from range $<0 ; 1>$ when calculated in relative numbers, or $<0,100>$ if we calculate percentage results. In practice, the concentration ratio is commonly quantified for three, five or ten strongest companies in the industry (quantification of indicators $C R_{3}, C R_{5}$ and $C R_{10}$ ). In some other studies, authors prefer indicators $C R_{4}$ and $C R_{8}$ quantified for four and eight strongest subjects $[13,17,18]$.

\subsubsection{Herfindahl index}

Herfindahl index measures the absolute concentration in the industry. In the literature we may also find the concept of the Herfindahl-Hirschmann index [11]. It is widely used for sector analysis and it is well-known and commonly accepted indicator of market competitiveness [6]. It explains, how financial power (business revenues) of individual subjects impacts the concentration of whole industry. Herfindahl index quantifies the square of the market share of each subject in the industry and sums up the resulting numbers [7].

Analytical expression of Herfindahl index is as follows [10]:

$$
H=\sum_{k=1}^{n}\left(\frac{q_{k}}{q}\right)^{2}
$$

and the meaning of the variables remains identical, as in the previously defined formulas.

Herfindahl index $H$ takes values from $<1 / n, 1>$. Extreme low value $H=1 / \mathrm{n}$ means that every company has equal market share in the industry. For extreme upper level, for which $H=1$ there is a pure monopoly on the market - one company produces $100 \%$ of whole industry production [5].

In practice, the Herfindahl index may not be used as a number of the interval mentioned above - because in sectors with a higher number of enterprises we would operate with very low numbers. Therefore, the value of $H$ tends to be adjusted by the appropriate multiplier, most commonly used multiplier is 10,000 . Depending on what is the value $H$ after conversion, we can classify the degree of concentration of the industry, according to the following criteria defined by the US Federal Trade Commission (FTC) : 
- for $H<1500$, the industry is not concentrated,

- for $H$ is in the range of $\langle 1500 ; 2500\rangle$, the industry is moderately concentrated,

- for $H>=2500$, the industry is concentrated [22]. Herfindahl index values also impact how government sets and enforces competition policy [16].

The Herfindahl index as used currently was firstly applied in 1950 in dissertation thesis of O. C. Herfindahl. Later, in 1959 he used it in a study about international copper industry [12]. The similar concept (sum of squared market shares), however is known since 1940 when A. O. Hirshmann executed a trade study. Hirschmann in his paper suggests that original idea of index belongs to him [13]. Therefore, in the literature we can find concepts of Herfindahl index or Hirchmann-Herfindahl index, but both of them represent the same indicator.

Herfindahl index has been used in multiple studies to consider competition level in variety of industries, for example in banking, insurance, automotive or creative industry [1, $5,9,14,15,19,20,23]$. Its construction, however, has some limitations - it can measure concentration only on geographically isolated markets, but cannot be applied for international companies, as the results may be misleading [2].

\subsection{Quantification of selected indicators}

This chapter presents and discusses calculated results, which are listed in following tables separately for different indicators - market share, concentration ratio and Herfindahl index. Table 2, Table 3 and Table 4 complete all data needed for the research purposes.

\subsubsection{Quantification of market share}

According to revenues data listed in Table 3, it was possible to calculate the market share of observed businesses. Market share is expressed in \% and following table (Table 5) illustrates the relative strenght of businesses based on the amount of revenues.

Table 5. Market share of Slovak bicycle manufacturers during observed period 2020-2016 (\%)

\begin{tabular}{|l|l|c|c|c|c|c|}
\hline & & $\mathbf{2 0 2 0}$ & $\mathbf{2 0 1 9}$ & $\mathbf{2 0 1 8}$ & $\mathbf{2 0 1 7}$ & $\mathbf{2 0 1 6}$ \\
\hline 1. & KELLYS BICYCLES s.r.o. & 58,43 & 52,69 & 59,86 & 58,70 & - \\
\hline 2. & BELVE, s.r.o. & 22,81 & 18,31 & 18,65 & 19,16 & 43,31 \\
\hline 3. & DEMA Senica, a.s. & 15,54 & 25,51 & 18,12 & 18,69 & 48,51 \\
\hline 4. & LIBERTY TRADE, s.r.o. & 1,23 & 1,54 & 1,72 & 1,81 & 4,58 \\
\hline 5. & Kenzel, s.r.o. & 0,93 & 1,17 & 0,87 & 1,03 & 1,99 \\
\hline 6. & Cyclision s.r.o. & 0,74 & 0,40 & 0,29 & - & - \\
\hline 7. & ISTRO - HGA, spol s r.o & 0,30 & 0,38 & 0,49 & 0,61 & 1,61 \\
\hline
\end{tabular}

The power distribution between bicycle manufacturers reflects that three businesses (Kellys Bicycles, Belve and Dema Senica) keep the distance from other four (Liberty Trade, Kenzel, Cyclision and Istro-Hga), as the leading trio control almost $97 \%$ of the market. The leading company - Kellys Bicycles clearly holds top position during observed period with approximately $58 \%$ of market share.

Second strongest business is Belve, as it covers almost $23 \%$ of the market, while Dema Senica holds third place with more than $15 \%$ of market share. Data also show changes in power balance within the industry. In 2016, only five manufacturers were on the market and Dema Senica possessed almost one half of the market. However, during next four years 
Kellys Bicycles and Belve gained momentum and Dema Senica was subsequently squeezed from the first to the third position.

Among the four weakest players, there are not any significant changes between 2016 and 2020. All businesses together - Liberty Trade, Kenzel, Cyclision and Istro-Hga are currently accounting for approximately $3 \%$ of the market, therefore their impact on the sector is almost negligible. Trinity of top manufacturers clearly dictate conditions of the Slovak bicycle manufacturing sector. Production among other four businesses is significantly fragmented and none of them comes close to the revenues level of top three producers.

\subsubsection{Quantification of concentration ratio}

Concentration ratio of industry is dependant on market share values. As already mentioned before, concentration ratio in the industry is most often calculated for three, five and ten strongest companies in the industry. As we analyze the sector with only seven businesses, $C R_{10}$ quantification is not relevant. Table 6 contains already calculated concentration levels $C R_{3}$ and $C R_{5}$ for the bicycle manufacturing industry in Slovakia, based on revenues achieved by enterprises in the relevant period.

Table 6. Concentration Ratio $C R_{3}, C R_{5}$ and of Slovak bicycle manufacturing industry (\%)

\begin{tabular}{|l|c|c|c|c|c|}
\hline & $\mathbf{2 0 2 0}$ & $\mathbf{2 0 1 9}$ & $\mathbf{2 0 1 8}$ & $\mathbf{2 0 1 7}$ & $\mathbf{2 0 1 6}$ \\
\hline$C R_{3}$ & 96,78 & 96,51 & 96,63 & 96,55 & 96,4 \\
\hline$C R_{5}$ & 98,94 & 99,22 & 99,22 & 99,39 & 100 \\
\hline
\end{tabular}

The results show stable development of concentration ratio during the period. Concentration ratio $C R_{3}$ represents the share of three strongest manufacturers which constantly control almost $97 \%$ of local bicycle manufacturing industry. Their position remained absolutely dominant even during COVID-19 recession and probably anything can threaten it in the near future. Moreover, their hegemony is not short-term at all - top three businesses dominate the market throughout whole monitored period .

Concentration ratio $C R_{5}$ reaches similar values as $C R_{3}$. This is caused by the fact, that fourth and fifth strongest business (Liberty Trade and Kenzel) account only for 2,16\% of the market. As we stated above, the dynamics of the whole industry is influenced by three biggest players and four remaining companies have only minimal impact on the market operation.

Concentration ratios $C R_{3}$ and $C R 5$ did not record any fluctuations between years 2016 and 2020. Comparison of both indicators makes it possible to state that Slovak bicycle manufacturing industry shows signs of oligopolistic market structure - with three very strong and four very small companies operating within the sector.

\subsubsection{Herfindahl index quantification}

A first step before Herfindahl index quantification, a key metric evaluating a degree of industry concentration, we determined the number of businesses in the sector to $7(n=7)$. Despite the number of industry participants is relatively low, it is still possible to execute Herfindahl index quantification. Based on the business revenues and market share, values of Herfindahl index were calculated and then collected in Table 7.

Table 7. Herfindahl index of Slovak bicycle manufacturing industry in years 2016-2020

\begin{tabular}{|l|l|l|l|l|l|}
\hline & 2020 & 2019 & 2018 & 2017 & 2016 \\
\hline
\end{tabular}




\begin{tabular}{|l|c|c|c|c|c|}
\hline $\begin{array}{l}\text { Herfindahl } \\
\text { index H }\end{array}$ & 4179,9 & 3766,2 & 4263,1 & 4166,6 & 4390,6 \\
\hline
\end{tabular}

Herfindahl index as a complex indicator assesses the degree of industry concentration. During the analyzed period, values of Herfindahl index stay in the range of $<3766,2$; 4390,6>. According to generally accepted methodology of the Federal Trade Commission (FTC), the industry can be classified as concentrated (because values of Herfindahl index sigbificantly exceed 2500) [22]. This suggestion is supported by other criterion where Herfindahl index for concentrated industry takes values which are higher than $1800[5,10]$.

Herfindahl index values calculated for Slovak bicycle manufacturing industry classify it as concentrated industry. Based on the quantified results, it could be also defined as highly concentrated industry. Currently, only seven subjects are operating within the industry while three of them have dominant position in the sector as they account for $97 \%$ of the total industry revenue, what underlines the thesis of a highly concentrated industry. Three strongest entities possess such a power that makes it very difficult for other competitors to expand their market activities.

\section{Summary/Conclusion}

Results obtained from the research prove that Slovak bicycle manufacturing industry is almost exclusively dependent on performance of three strongest producers. Analysis and explanation of quantified indicator values enable us to state that sector of bicycle manufacturers in Slovakia undoubtly shows signs of highly concentrated industry. According to methodology for Herfindahl index calculation, Slovak bicycle manufacturing industry ranks in the category of highly concentrated industries what means relatively low competition level and unsuitable conditions for enterpreneurship within the sector.

However, the industry in the Slovak Republic has recorded succesful development in past years, which was caused mainly by increased demand for bicycles. Moreover, sales of bicycles also increased during the COVID-19 crisis and global bicycle industry was one of few sectors not affected by economic slump.

As global trends favor a healthy lifestyle, ecological solutions, green mobility and environmental sustainability, further expansion can be expected for bicycle industry, even in the conditions of Slovak Republic.

\section{Acknowledgement}

This paper is one of the partial outputs of the research grant no. I-21-107-00 entitled "Analysis of factors influencing the development of green mobility in the context of business sphere of the Slovak Republic", led by Ing. Vladimír Hojdik. PhD., University of Economics in Bratislava, Faculty of Business Management, Department of Business Economy. 


\section{References}

1. F. M. Aijde, J. O. Ajileye, Market concentration and Profitability in Nigerian Banking Industry: Evidence from Error Correctiion Modeling. International Journal of Economics, Commerce and Management 3, 1-12 (2015)

2. P. Aghion, N. Bloom, R. Blundell, Competition and Innovation : An Inverted-U Relationship. Quarterly Journal of Economics 120 (2), 701-728 (2005) DOI : 10.1093/qje/120.2.701

3. J. A. Bikker, K. Haaf, Competition, concentration and their relationship : an empirical analysis of the banking industry. Journal of Banking and Finance 26, 2191-2214 (2002) DOI :10.1016/S0378-4266(02)00205-4

4. T. Blondiau, B. van Zeebroeck, H. Haubold, Economic Benefits of the increased cycling. Transportation Research Procedia 14, 2306-2313 (2016) DOI : 10.1016/j.trpro.2016.05.247

5. I. Brezina, A. Oršulová, J. Pekár, Analýza absolútnej koncentrácie vybraného odvetvia pomocou Herfindahlovho-Hirschmannovhio indexu, Ekonomický časopis 57 (1) 77-94 (2009)

6. I. Brezina, J. Pekár, Z. Čičková, M. Reiff, Herfindahl-Hirschmann index level of concentration values modification and analysis of their change, Central European Journal of Operations Research 24, 49-72 (2016) DOI : 10.1007/s10100-014-0350-y

7. M. C. Cavalleri, A. Eliet, P. McAdam, Concentration, market power and dynamism in the euro area. ECB Working Paper Series, Discussion Paper No. 2253, European Central Bank (2019) DOI :10.2866/379250

8. Database of Slovak Businesses and Organizations. (2021) Available at $<$ https://www.finstat.sk >

9. J. Fedderke, D. Naumann, An Analysis of Industry Concentration in South African Manufacturing 1972-2001, Applied Economics 43, 2919-2939 (2011) DOI : 10.1080/00036840802631835

10. M. Fendek, E. Fendeková, Mikroekonomická analýza (Iura Edition, Bratislava, 2008)

11. G. Grullon, Y. Larkin, R. Michaely, Are US industries becoming more concentrated ? Forthcoming, Review of Finance (2017)

12. O. C. Herfindahl, Copper Costs and Prices : 1870-1957 (Baltimore, The John Hopkins Press, 1964)

13. A. O. Hirschmann, The Paternity of an Index, American Economic Review 54, 761-762 (1964)

14. V. Hojdik, Evaluation of Slovak Automotive Industry Competitiveness Based on Market Concentration Indicators. SHS Conferences 83 (2020) : Current Problems of the Corporate Sector 2020 : 17th Scientific Conference. - Paris : Edition Difussion Presse Sciences. DOI : 10.1051/shfconf/20208301022

15. M. Kozáková, M. Kmety Barteková, Analysis of market concentration in creative industry. SHS Conferences 83 (2020) : Current Problems of the Corporate Sector 2020 : 17th Scientific Conference. - Paris : Edition Difussion Presse Sciences. DOI : 10.1051/shfconf/20208301022

16. P. MacKay, G. M. Phillips, How Does Industry Affect Firm Financial Structure ? The Review of Financial Studies 18 (4), (2005) DOI : 10.1093/rfs/hhi032 
17. E. Nauenberg, K. Basu, H. Chand, Hirshmann-Herfindahl Index Determination under Incomplete Information, Applied Economics Letters 4 (10), 639-642 (1997) DOI : $10.1080 / 758533291$

18. S. Rhoades, The Herfindahl-Hirshmann index, Federal Reserve Bank of St. Louis 52 (3), 188-189 (1993)

19. Z. E. L. Rolim, R. R. Oliveira, H. M. Oliveira, Industrial Concentration of the Brazilian Automobile Market and Positioning in the World Market, Working Paper (2019) DOI :10.13140/RG.2.2.11210.11207

20. M. N. Al Arif Rianto, T. B. Awwaliyah, Market share, concentration ratio and profitability : Evidence from Indonesian Islamic Banking Industry. Journal of Central Banking Theory and Practice 2, 189-201 (2019) DOI : 10.2478/jcbtp-2019-0020

21. Statistical Office of Slovak republic, Yearbook of Industry of the SR 2019 (Bratislava, 2019)

22. U.S. Department of Justice and Federal Trade Commision, Horizontal Merger Guidelines, (2010)

23. D. M. L. Williams, P. Molyneux, J. Thornton, Market Structure and Performance in Spanish Banking. Journal of Banking and Finance 18, 433-443 (1994) DOI :10.1016/0378-4266(94)90002-7 